\title{
Persistent Müllerian duct syndrome in a beluga whale Delphinapterus leucas
}

\author{
Raphaela Stimmelmayr ${ }^{1,2, *}$, Tatiana Ferrer ${ }^{3}$, David S. Rotstein $^{4}$ \\ ${ }^{1}$ Department of Wildlife Management, North Slope Borough, Utqiagvik, AK 99723, USA \\ ${ }^{2}$ Institute of Arctic Biology, University of Alaska Fairbanks, 757000, Fairbanks, AK 99775-70, USA \\ ${ }^{3}$ Harbor Branch Oceanographic Institute, Florida Atlantic University, Fort Pierce, FL 34946, USA \\ ${ }^{4}$ Marine Mammal Pathology Services, Olney, MD 20832, USA
}

\begin{abstract}
This case study describes a persistent Müllerian duct syndrome (PMDS), a rare form of XY disorder of sex development (DSD), in a mature (>15 yr) beluga whale Delphinapterus leucas. The phenotypically and genetically male beluga whale had both Müllerian (paramesonephric) and Wolffian (mesonephric) duct derivatives. A mild hydrometra was present. Gross and histological analyses indicated the testes were atrophied. Histopathologic findings in the testes also included fibrosis in addition to ductus deferens ductular dilation, epididymal ductular dilation, lymphoplasmacytic balanitis, uterine glandular atrophy, and endometrial fibrosis. DSDs are rarely reported in cetaceans, and PMDS has never been described in a cetacean.
\end{abstract}

KEY WORDS: Beluga whale $\cdot$ Delphinapterus leucas $\cdot$ Developmental sex disorder $\cdot$ Anti-Müllerian hormone $\cdot \mathrm{AMH} \cdot \mathrm{AMH}$ receptor $\cdot$ Persistent Müllerian duct syndrome

\section{INTRODUCTION}

Disorders of sex development (DSDs), formerly described as intersex, are defined as congenital conditions associated with atypical development of chromosomal, gonadal, or anatomical sex (Hughes 2008, Meyers-Wallen 2012). While DSDs have been well studied in humans and domestic species, this is not the case for most wildlife (Mastromonaco et al. 2012). Among aquatic mammals, DSDs have predominantly been reported in cetaceans. In both baleen and toothed whales, XY DSD or XX DSD (formerly pseudohermaphrodism) are the most frequently reported. In 4 of the 5 published DSD case reports, the individuals were phenotypically female: striped dolphin Stenella coeruleoalba (Niseiiwaki 1953), fin whale Balaenoptera physalus (Bannister 1963), bowhead whale Balaena mysticetus $(\mathrm{n}=2$; Tarpley et al. 1995); with only one phenotypically male (a beluga whale Delphina-

${ }^{*}$ Corresponding author:

raphaela.stimmelmayr@north-slope.org pterus leucas; Mikaelian et al. 2003). Ovotesticular DSD (true hermaphrodism; XY sex reversal), with presence of both types of gonads and ovotestes, has been reported in the common dolphin Delphinus delphis (Murphy et al. 2011) and the beluga whale (De Guise et al. 1994). We report on the descriptive anatomy and microanatomical findings of persistent Müllerian duct syndrome (PMDS), a rare form of XY $\mathrm{DSD}$, in a beluga whale.

\section{MATERIALS AND METHODS}

As part of the North Slope Department of Wildlife Management (NSB DWM) Beluga Whale Subsistence Harvest Monitoring Program in Alaska (Frost \& Suydam 2010), opportunistic tissue samples from a subsistence harvested beluga whale with an estimated body length of at least $3.96 \mathrm{~m}$ (tip of the snout

() The authors 2019. Open Access under Creative Commons by Attribution Licence. Use, distribution and reproduction are unrestricted. Authors and original publication must be credited. 
to fluke insertion; fluke had been removed by hunter) were collected on the beach during August 2017 in Utqiagvik, Alaska (71.2906 $\left.{ }^{\circ} \mathrm{N}, 156.7886^{\circ} \mathrm{W}\right)$. The internal reproductive tract was transferred to the NSB DWM necropsy suite and stored frozen $\left(-20^{\circ} \mathrm{C}\right)$ until analyzed.

\subsection{Histology and gross morphology}

Sex identification was determined by palpation of the genital slit for the presence or absence of the penis. Tissue samples were collected from the derivatives of the paramesonephric duct (uterus, uterine horn, uterine tube) and mesonephric duct (testis, epididymis, ductus deferens) and fixed in $10 \%$ neutralbuffered formalin. The tissues were processed for paraffin histology, sectioned at 4-6 $\mu \mathrm{m}$, and stained with hematoxylin and eosin (H\&E; Histology Consultation Services). Reproductive organs were evaluated for the presence of normal architecture and in the case of gonads, developmental and maturational stages. Standard morphometric measurements (length and width) using a ruler were taken of the Müllerian and Wolffian duct derivatives.

\subsection{Genetics}

A liver sample was frozen at $-50^{\circ} \mathrm{C}$ and submitted for a PCR-based method for gender determination (Palsbøll et al. 1992). A sample was extracted using a DNeasy Blood \& Tissue Kit (Qiagen). Total DNA was quantified by spectrophotometry on a NanoDrop, and a dilution of $10 \mathrm{ng}^{-1}$ was aliquoted, ensuring a known quantity of DNA was added to the PCR reaction.

Sex was determined by co-amplifying the ZFX genes (Aasen \& Medrano 1990) and the SRY genes (Fain \& LeMay 1995) (see Tables A1-A3 in the Appendix). Females (XX) have a single band around 400 bp long and males (XY) have 2 bands, one at about $400 \mathrm{bp}$ and one around $200 \mathrm{bp}$ (Palsbøll et al. 1992). The sample was independently amplified twice, and each time a negative control was included to ensure contamination was not a factor.

\section{RESULTS}

Externally, a normally developed penis was located in the genital slit. Mammary slits were absent. The urethra opened at the tip of the penis (Fig. 1A). During field examination of the abdominal body cavity, a female reproductive tract-like structure with paired gonadal tissues was observed. (Fig. 1B). Both the uterine horns and uterus body were filled with redtinged viscous fluid $\left(104 \mathrm{~cm}^{3}\right)$. The inner lining of the short uterine body was smooth and the uterine horns had diagonal pleats arranged in 2 rows separated by a section of smooth lining starting at the tip of the horns and extending approximately midway the lengths of both horns (Fig. 1C). Between 4 and 9 longitudinal pleats extended the entire length of the upper vagina (Fig. 1C). The constriction of the uterine body marking the transition to the vagina and the circular (transverse) folds of the vaginal mucosa characterizing the os uteri of the cervix were absent, ending the vagina blindly. Small, underdeveloped testes and epididymides were tightly attached to the uterine tubes (Fig. 1B). At the confluence of the uterine tube (syn. fallopian tube; oviduct) and uterine horn, both uterine tubes were without a visible lumen and ending blindly. The highly tortuous vas deferens (syn. ductus deferens) followed the entire length of the uterine horns and fused midway with the uterus wall. The opening of both vas deferens was visualized lateral to the pelvic urethra in the transverse section (Fig. 1D). Detailed morphometric measurements (length $\times$ width) of the respective reproductive structures are summarized in Table 1.

Microscopically, uterine tubes had an orderly arrangement of layers. There were no glands and the lining endometrial mucosal epithelial cells were attenuated. Uterine horn glands were reduced in number and size and separated by abundant supporting stroma (Fig. 2B). Histopathologic findings in the

Table 1. Morphometrics (length and width) of paramesonephric and mesonephric duct derivatives in a male mature beluga whale Delphinapterus leucas taken by subsistence hunt, during August 2017, Utqiagvik, Alaska

\begin{tabular}{|lcc|}
\hline Reproductive structure & Length (mm) & Width (mm) \\
\hline Uterine body & 60 & 40 \\
Uterine horn & & \\
$\quad$ Right & 105 & 50 \\
Left & 120 & 60 \\
Uterine tube & & \\
Right & 100 & 4 \\
Left & 110 & 7 \\
Vagina & 145 & \\
Testis & & 40 \\
Right & 85 & 40 \\
Left & 95 & 40 \\
Epidydimis & & 40 \\
Right & 140 & \\
Left & 190 & \\
\hline
\end{tabular}



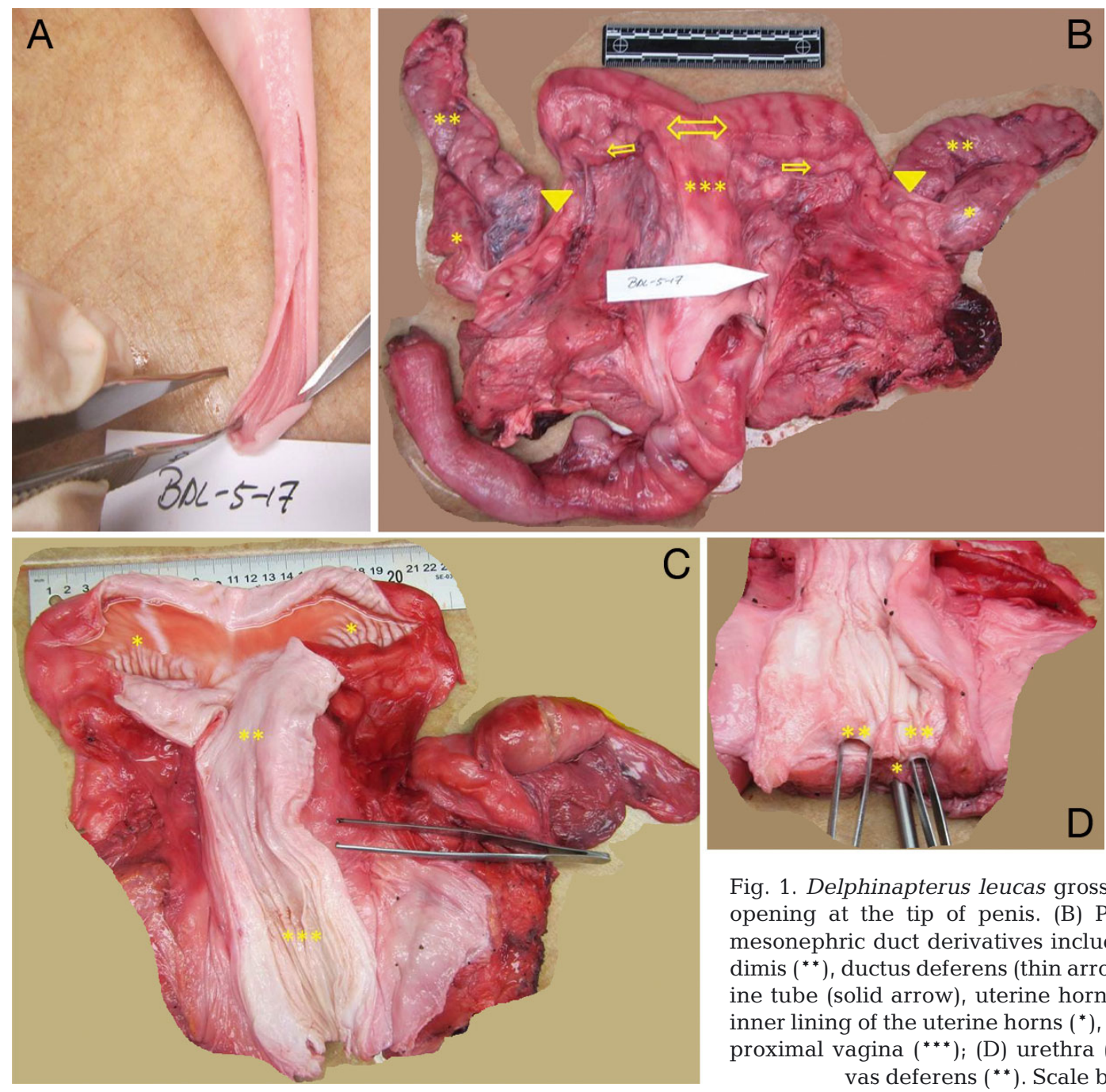

Fig. 1. Delphinapterus leucas gross images. (A) Urethra opening at the tip of penis. (B) Paramesonephric and mesonephric duct derivatives including testis $\left({ }^{*}\right)$, epidy$\operatorname{dimis}\left({ }^{* *}\right)$, ductus deferens (thin arrow), uterus $\left({ }^{* * *}\right)$, uterine tube (solid arrow), uterine horns (double arrow); (C) inner lining of the uterine horns $\left({ }^{*}\right)$, uterine body $\left({ }^{* *}\right)$ and proximal vagina $\left({ }^{* * *}\right)$; (D) urethra $\left({ }^{*}\right)$ and right and left vas deferens $\left({ }^{* *}\right)$. Scale bar is in $\mathrm{cm}$
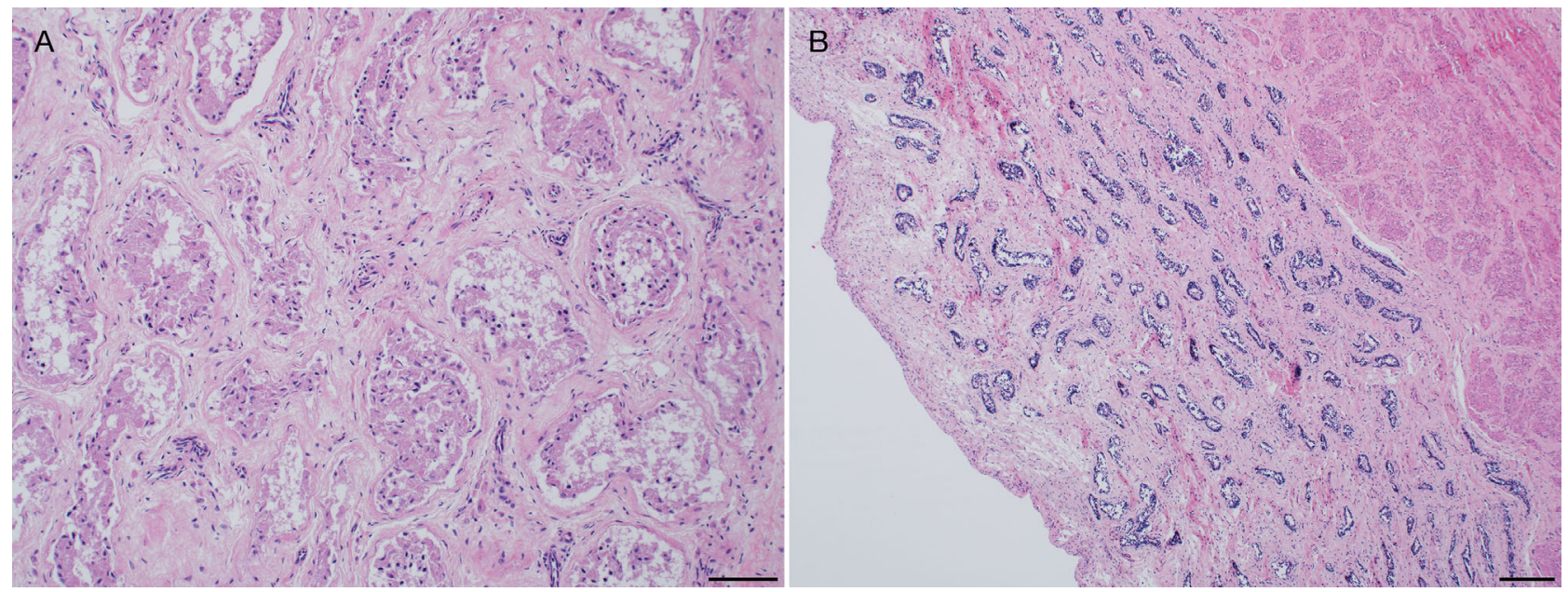

Fig. 2. Delphinapterus leucas histopathology. Hematoxylin and eosin. (A) Testicular seminiferous tubules are atrophied. Lumina are dilated with spermatagonia and spermatazoa not present. Tubules are separated by collagen (fibrosis). Scale bar $=$ $100 \mu \mathrm{m}$. (B) Uterine glands are reduced in sized and separated by abundant stroma. Scale bar $=200 \mu \mathrm{m}$ 
testis included seminiferous tubular atrophy and interstitial fibrosis (Fig. 2A). Few tubules had spermatagonia and few spermatozoa. Epididymal ducts were dilated with mucosal infolding and ductular separated by variably dense collagen. Few ducts contained spermatozoa. The presence of 2 bands on the agarose gel indicates PCR amplification of fragments from both the X (ZFX) and Y (SRY) chromosomes (Fig. 3), confirming that the individual was genetically male.

\section{DISCUSSION AND CONCLUSIONS}

The beluga whale taken by a subsistence hunter from Utqiagvik, Alaska, most likely belonged to the Eastern Beaufort stock (O'Corry-Crowe et al. 2018). Based on body length and white skin coloration, the male was mature with an estimated age of at least 15 yr (Burns \& Seaman 1988). Reproductive anomalies, including DSDs, have not been reported for the 5 subpopulations of belugas known to occur in the Bering, Chukchi, and Beaufort seas. However, 2 DSD cases have been reported for the endangered, genetically and geographically isolated, non-migratory St. Lawrence Estuary beluga whale stock (De Guise et al. 1994, Mikaelian et al. 2003).

This is the first report of PMDS in cetaceans. An undifferentiated Müllerian duct remnant has been previously reported in a white beaked dolphin Lagenorhynchus albirostris (Meek 1918), but not PMDS. PMDS, a rare form of XY DSD, whose molecular background has been determined in humans, 2 dog breeds, and the house mouse, is caused by gene mutations affecting either the synthesis of anti-Müllerian hormone $(\mathrm{AMH}$; Müllerian inhibiting substance) or its action by modifying its type II receptor (MISRII/ AMHR2) (Behringer et al. 1994, Wu et al. 2009, Picard et al. 2017). AMH deficiency permits differentiation of the Müllerian duct into the uterus, uterine tubes, and the upper vagina. Hormone-mediated male sex differentiation proceeds otherwise normally with non-ambiguous external masculinization and differentiation of internal gonads (testis, epidydimis, vas deferens) from the mesonephric duct (Wolffian duct). In other terrestrial species, PMDS has rarely been reported, and determination of the molecular background is lacking (Schulman \& Levine 1989, Haibel \& Rojko 1990, Meyers-Wallen 2012, Panasiewicz et al. 2015). In this case, the genetic basis (i.e. gene mutations) of PMDS was not determined, as commercially available genetic tests available for canids (Wu et al. 2009) have not been validated for

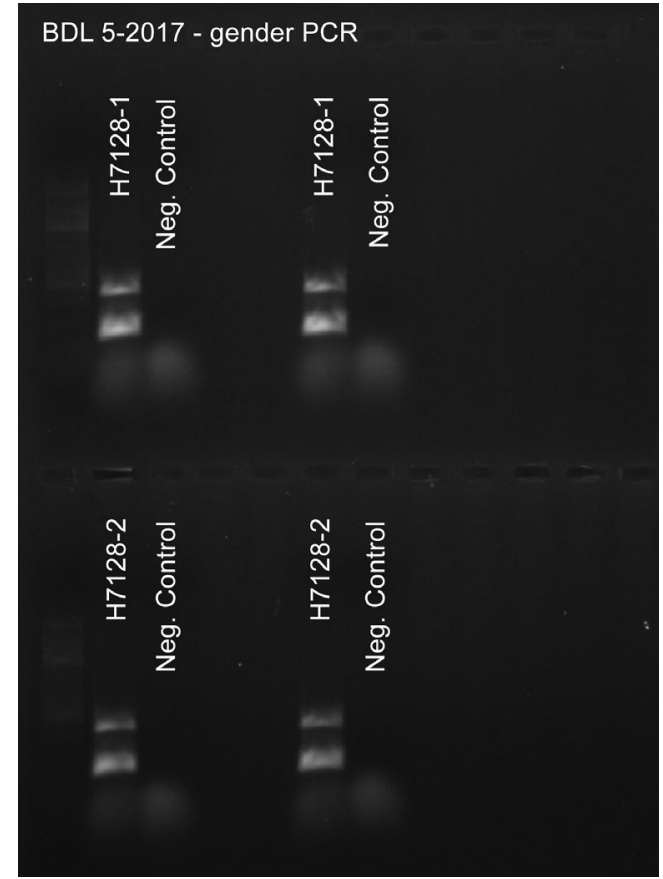

Fig. 3. Delphinapterus leucas PCR amplification products of the ZFX and SRY regions of the X and Y chromosomes on agarose gel. Determination of male gender was based on the number of bands for the individual, one corresponding to the $\mathrm{X}$ chromosome and one to the Y. Sample was amplified twice on 2 separate occasions and each run with a negative control, ensuring results were reproducible and no contamination occurred

cetaceans. PMDS in the beluga whale presented similar to PMDS-affected male dogs, with external and cytogenetical male traits, bilateral testes tethered tightly to the uterine tubes, vas deferens included in the lateral walls of the uterus, and presence of a mostly complete Müllerian duct system (uterus, uterine tubes, upper vagina) with only the cervix absent (Meyers-Wallen 2012). The observed oblique organization of the folds in the uterine horns and the absence of longitudinal folds in the uterus body most likely represent a morphological variation related to PMDS. Longitudinal folds in both the uterine body and horns of a female beluga whale have been described previously by Watson \& Young (1880). Uterus size was comparable to that of an immature female beluga whale (uterine body: $51 \mathrm{~mm}$; uterine horns: $152 \mathrm{~mm}$; uterine tube: $76 \mathrm{~mm}$; Watson \& Young 1880)

In this whale, testicular atrophy was observed grossly and histologically (multifocal, moderate atrophy with interstitial fibrosis). There was minimal spermatogenesis. Given that peak breeding season for beluga whales in Alaska is thought to occur 
between late February and early April, and adult male beluga whales sampled during April and May already showed 'retrogression phase of the annual cycle of spermatogenesis' (Burns \& Seaman 1988), we cannot rule out that minimal spermatogenesis in our case also reflects timing of the breeding season. Overall testes size (length $\times$ width) was much smaller $(85-90 \times 40 \mathrm{~mm})$ than a mature, similar sized male beluga whale $(195 \times 85 \mathrm{~mm})$ harvested the same day. Testosterone production was not determined in this animal, but the phenotypic male appearance and spermatogenesis (albeit limited and rare spermatozoa on histology) suggests functional Sertoli and Leydig cells. In dogs with PMDS, about $50 \%$ of individuals with unilateral cryptorchidism have normal testosterone production, and dogs are fertile (Wu et al. 2009). Additional sequela observed in dogs with PMDS include uterine diseases (pyometra; hydrometra) and testicular tumors of the cryptorchid testis (Matsuu et al. 2009, Wu et al. 2009). In cetaceans, intra-abdominal location of testis is physiological, with testicular tumors being rare (Díaz-Delgado et al. 2012). In this case, additional sequela was observed in the form of a hydrometra.

Acknowledgements. We thank the beluga hunters from Utqiagvik, Alaska for allowing us to collect samples and conduct the study. This study was funded by the North Slope Borough, Department of Wildlife Management (NSBDWM). Marine mammal tissue collection occurred under NMFS permit \#17350- 02 issued to the NSB-DWM.

\section{LITERATURE CITED}

Aasen E, Medrano JF (1990) Amplification of the ZFY and ZFX genes for sex identification in humans, cattle, sheep and goats. Nat Biotechnol 8:1279-1281

Bannister JL (1963) An intersexual fin whale Balaenoptera physalus (L.) from South Georgia. Proc Zool Soc Lond 141:811-822

Behringer RR, Finegold MJ, Cate RL (1994) Müllerianinhibiting substance function during mammalian sexual development. Cell 79:415-425

Burns JJ, Seaman GA (1988) Investigations of belukha whales in coastal waters of western and northern Alaska. II. Biology and ecology. Outer Continental Shelf Environmental Assessment Program, Vol 56. US Department of Commerce, NOAA, Anchorage, AK, p 221-357

* De Guise S, Lagacé A, Béland P (1994) True hermaphroditism in a St. Lawrence beluga whale (Delphinapterus leucas). J Wildl Dis 30:287-290

* Díaz-Delgado J, Espinosa de los Monteros A, FernándezMaldonado C, Arbelo M, Quesada-Canales O, Andrada M, Fernández A (2012) Mixed testicular neoplasia in a short beaked common dolphin Delphinus delphis. Dis Aquat Org 101:257-260
Fain SR, LeMay JP (1995) Gender identification of humans and mammalian wildlife species from PCR amplified sex linked genes. Proc Am Acad Forensic Sci 1:34

Frost K, Suydam R (2010) Subsistence harvest of beluga or white whales (Delphinapterus leucas) in northern and western Alaska, 1987-2006. J Cetacean Res Manag 11: 293-299

* Haibel GK, Rojko JL (1990) Persistent Müllerian duct syndrome in a goat. Vet Pathol 27:135-137

*Hughes IA (2008) Disorders of sex development: a new definition and classification. Best Pract Res Clin Endocrinol Metab 22:119-134

* Mastromonaco GF, Houck ML, Bergfelt DR (2012) Disorders of sexual development in wild and captive exotic animals. Sex Dev 6:84-95

Matsuu A, Hashizume T, Kanda T, Nagano M, Sugiayam A, Okamota Y, Hikasa Y (2009) A case of persistent Müllerian duct syndrome with Sertoli cell tumor and hydrometra in a dog. J Vet Med Sci 71:379-381

Meek A (1918) The reproductive organs of Cetacea. J Anat 52:186-210

Meyers-Wallen VN (2012) Gonadal and sex differentiation abnormalities of dogs and cats. Sex Dev 6:46-60

Mikaelian I, Labelle P, Kopal M, De Guise S, Martineau D (2003) Adenomatous hyperplasia of the thyroid gland in beluga whales (Delphinapterus leucas) from the St. Lawrence Estuary and Hudson Bay, Quebec, Canada. Vet Pathol 40:698-703

Murphy S, Deaville R, Monies RJ, Davison N, Jepson PD (2011) True hermaphroditism: first evidence of an ovotestis in a cetacean species. J Comp Pathol 144: 195-199

Niseiiwaki M (1953) Hermaphroditism in a dolphin (Prodelphinus caeruleoalbus). Sci Rep Whal Res Inst Tokyo 8: 215-218

* O'Corry-Crowe G, Suydam R, Quakenbush L, Potgieter B and others (2018) Migratory culture, population structure and stock identity in North Pacific beluga whales (Delphinapterus leucas). PLOS ONE 13:e0194201

* Palsbøll PJ, Vader A, Bakke I, El-Gewely MR (1992) Determination of gender in cetaceans by the polymerase chain reaction. Can J Zool 70:2166-2170

*Panasiewicz G, Zamojska A, Bieniek M, Gizejewski Z, Szafranska B (2015) Persistent Müllerian duct syndrome (PMDS) in the Polish free-ranged bull populations of the European bison (Bison bonasus L.). Anim Reprod Sci 152: 123-136

* Picard JY, Cate RL, Racine C, Josso N (2017) The persistent Müllerian duct syndrome: an update based upon a personal experience of 157 Cases. Sex Dev 11:109-125

* Schulman J, Levine SH (1989) Pyometra involving uterus masculinus in a cat. J Am Vet Med Assoc 194:690-691

* Tarpley R, Jarrell G, George J, Cubbage J, Stott G (1995) Male pseudohermaphroditism in the bowhead whale, Balaena mysticetus. J Mammal 76:1267-1275

Watson M, Young A (1880) XI. The anatomy of the northern beluga (Beluga catodon, Gray; Delphinapterus leucas, Pallas) compared with that of other whales. Trans R Soc Edinb 29:393-435

*Wu X, Wan S, Pujar S, Haskins ME, Schlafer DH, Lee MM, Meyers-Wallen VN (2009) A single base pair mutation encoding a premature stop codon in the MIS type II receptor is responsible for canine persistent Müllerian duct syndrome. J Androl 30:46-56 
Appendix. Details of PCR used for sex determination

Table A1. Primer sequences and references

\begin{tabular}{|llcc|}
\hline Primer & Sequence $\left(5^{\prime}-3^{\prime}\right)$ & Fragment length (bp) & Reference \\
\hline ZFX-P1-5EZ & ATA ATC ACA TGG AGA GCC ACA AGC T & $\sim 400$ & Aasen \& Medrano (1990) \\
ZFX-P2-3EZ & GCA CTT CTT TGG TAT CTG AGA AAG T & & Fain \& LeMay (1995) \\
SRY-Y53-3C & CCC ATG AAC GCA TTC ATT GTG TGG & $\sim 200$ & \\
SRY-Y53-3D & ATT TTA GCC TTC CGA CGA GGT CGA TA & & \\
\hline
\end{tabular}

Table A2. PCR thermocycling conditions

\begin{tabular}{|lccc|}
\hline Step & $\begin{array}{c}\text { Temp. } \\
\left({ }^{\circ} \mathrm{C}\right)\end{array}$ & $\begin{array}{c}\text { Time } \\
(\text { min:s })\end{array}$ & Cycles \\
\hline Initial denaturation & 90 & $2: 30$ & 1 \\
Amplification & & & 30 \\
Denaturation & 94 & $0: 45$ & \\
Annealing & 68 & $1: 00$ & \\
Extension & 72 & $1: 30$ & \\
Final extension & 72 & $5: 00$ & 1 \\
\hline
\end{tabular}

Editorial responsibility: Stephen Raverty, Abbotsford, British Columbia, Canada
Table A3. PCR master mix

\begin{tabular}{|c|c|c|}
\hline Component & Conc. & Vol. reaction $^{-1}(\mu \mathrm{l})$ \\
\hline MilliQ $\mathrm{H}_{2} \mathrm{O}(18 \mathrm{M} \Omega)$ & - & 13.875 \\
\hline $10 \times$ Buffer $\left(\mathrm{MgCl}_{2}\right)$ & $20 \mathrm{mM}$ & 2.5 \\
\hline dNTPs & $10 \mathrm{mM}$ & 0.375 \\
\hline \multicolumn{3}{|l|}{ Primers } \\
\hline ZFX-P1-5EZ & $10 \mu \mathrm{m}$ & 0.75 \\
\hline ZFX-P2-3EZ & $10 \mu \mathrm{m}$ & 0.75 \\
\hline SRY-Y53-3C & $10 \mu \mathrm{m}$ & 0.75 \\
\hline SRY-Y53-3D & $10 \mu \mathrm{m}$ & 0.75 \\
\hline Taq polymerase & $\mathrm{U} \mu \mathrm{l}^{-1}$ & 0.25 \\
\hline DNA & $10 \mathrm{ng} \mathrm{l}^{-1}$ & 5 \\
\hline \multicolumn{2}{|c|}{ Total volume reaction ${ }^{-1}$} & 25 \\
\hline
\end{tabular}

Submitted: April 9, 2019; Accepted: August 29, 2019 Proofs received from author(s): November 7, 2019 